\title{
CROP PRODUCTIVITY AND NUTRIENT UPTAKE OF FENUGREEK (Trigonella foenum-graecum L.) AS INFLUENCED BY INTEGRATED NUTRIENT MANAGEMENT
}

\author{
M. Shamsun Naher", A. H. F. Fahim and M. A. Wadud \\ Spices Research Centre, BARI, Shibgonj, Bogra, Bangladesh
}

\begin{abstract}
A field experiment was carried out at Spices Research Centre, Shibgonj, Bogra during two consecutive years, 2013-2014 and 2014-2015 to evaluate the response of integrated nutrient management on nutrient uptake, protein content and seed yield of fenugreek (Trigonella foenumgraecum L.) var. BARI Fenugreek-2. The field experiment was conducted in combination with inorganic fertilizer and organic manure. The result showed that the treatment $\mathrm{T}_{7}$ compeises application of PM @ $4 \mathrm{t} \mathrm{ha}^{-1}+\mathrm{CF}$ (IPNS) produced the maximum seed yield $\left(2.1 \mathrm{t} \mathrm{ha}^{-1}\right)$ but statistically identical to $\mathrm{T}_{8}$ (VC @ $3 \mathrm{t} \mathrm{ha}^{-1}+\mathrm{CF}$ (IPNS) and $\mathrm{T}_{6}$ (CD 5 @ $\mathrm{ha}^{-1}+\mathrm{CF}$ (IPNS). In case of stover yield, the treatment $\mathrm{T}_{7}$ produced the highest yield $\left(4.89 \mathrm{t} \mathrm{ha}^{-1}\right)$. The grain yield was increased over control and ranged between 65.85 to $156.10 \%$. The treatments $T_{7}$ and $T_{8}$ resulted in higher nutrient use efficiency along with higher $\mathrm{N}, \mathrm{P}, \mathrm{K}$ and $\mathrm{S}$ uptake by the plant. The application of inorganic fertilizer along with manure influenced the nutrient concentration in fenugreek seed and stover yield. The higher seed with $\mathrm{N}, \mathrm{P}, \mathrm{K}$ and $\mathrm{S}$ concentrations were observed in the treatments where poultry manure @ $4 \mathrm{t} \mathrm{ha}^{-1}$ applied in combination with chemical fertilizers. The combined application of fertilizer and organic manure increased the organic carbon (OC \%), organic matter (OM \%), total $\mathrm{N}$, available $\mathrm{P}$ and available $\mathrm{S}$ in post harvest soils. The findings indicate that the integrated use of inorganic fertilizer and organic manure should be encouraged to improvement the deteriorating soil fertility and increased crop yield of fenugreek.
\end{abstract}

Keywords: Crop productivity, fenugreek, integrated nutrient management, soil fertility, spice

\footnotetext{
" Corresponding author email: mahmud.nahar@yahoo.com
}

Received: 20.03.2016 


\section{INTRODUCTION}

Fenugreek (Trigonella foenum-graecum L.) locally known as 'methi' belonging to the family- Leguminosae and Sub family-Papilionacea is widely used as spice and condiment to add flavor in various foods (Dwivedi et al., 2006) . Fenugreek is generally cultivated as leafy vegetable, condiment and medicinal purpose. Its fresh and tender leaves are contains iron, calcium, protein, vitamins and essential amino acids. It has a high medicinal value as it prevents constipation, removes indigestion, stimulates spleen and liver and is appetizing and diuretic (Kumar et al., 1997). Fenugreek roots are act as supply of nitrogen for plant as a result enriches the soil with nitrogen. Application of organic manure in addition with inorganic fertilizer has been found to be quite promising not only in maintaining higher productivity but also in providing $t$ stability in crop production (Nambiar et al., 1989). Vermicompost when integrated with reduced doses of inorganic fertilizers result in improved soil fertility, growth and yield of plant (Subbian, and Palaniappan, 1992). Poultry manure treatments along the lower level of NPK produced higher values for plant height, leaf area index and biomass of corn and crop grain yield (Boateng et al., 2006). Integration of poultry manure with synthetic chemical fertilizers can enhance the efficiency of nutrients uptake and availability to crop plant (Warren et al., 2006). Chemical fertilizers have deleterious effect on soil fertility, while integration of chemical fertilizers with organic manures and bio-fertilizers would be able to maintain soil fertility and sustain crop productivity (Jeyabal et al., 2000). The use of organic fertilizer in combination with inorganic fertilizers has been recommended for balancing soil fertility by several workers. In the context, the present study was carried out to find out the response of integrated nutrient management on nutrient uptake, protein content and seed yield of fenugreek (Trigonella foenum-graecum L.).

\section{MATERIALS AND METHODS}

Experiments were carried out at the research field of Spices Research Centre, Shibgonj, Bogra during rabi season, for two consecutive years, 2013-2014 and 20142015. The soil belongs to the AEZ-3 of Tista Karatoa Flood Plain. The soil was silt loam having $\mathrm{pH}$ 5.9. The initaial soil sample showed that PKSBMgZn deficiene (Table 1) whereas poultry manure have high amount of NPKS (\%) than Vermicompost and Cow-dung (Table 2). There were 8 treatment combinations. A blanket dose of $10 \mathrm{~kg} \mathrm{~S}, 2 \mathrm{~kg} \mathrm{~B}$ and $4 \mathrm{~kg} \mathrm{Zn}$ were used. The amount of $\mathrm{N}, \mathrm{P}$ and $\mathrm{K}$ was calculated by omitting the amount which was supplemented by organic manure. The treatment combinations are shown in table 4 .The field experiment was laid out in a randomized complete block design with three replications. The unit plot size was $3 \mathrm{~m}$ $x 2 \mathrm{~m}$. BARI Fenugreek-2 was used in this trial. The entire quantity of organic manure applied at 2 weeks before transplanting. All chemical fertilizer and $1 / 3^{\text {rd }}$ of urea applied during final land preparation. Rest of urea applied in two equal splits at 20 and 40 days after sowing (DAS). The crop was sown on 24 November 2013 and 17 November 2014 , respectively maintaining $40 \mathrm{~cm} * 10 \mathrm{~cm}$ spacing. The rest $\mathrm{N}$ was 
applied in two equal splits at 25 and 50 days after sowing (DAS). Two weeding were done at 30 and 45 DAS. Three irrigations were applied at 30,60 and 85 DAS. Thinning was done at $15 \mathrm{DAE}$ to maintain optimum plant populations. To control leaf spot and leaf blight disease, the crop was sprayed with "Amister Top" (Azoxystrobin + Difenoconazole) @ $1 \mathrm{ml} \mathrm{l}^{-1}$ of water. Three sprays were applied at 10 days interval, just after the disease symptoms was initiated. The crop was harvested on 12 March 2014 and 8 March 2015, respectively. Data on seed yield and stover yields were recorded at harvesting time. Pre and post harvest soils were also collected from the experimental field.

Table 1. Analytical data of initial soil of experimental site

\begin{tabular}{l|c|c|c|c|c|c|c|c|c|c|c}
\hline Texture & $\mathrm{p}^{\mathrm{H}}$ & $\mathrm{OM}$ & $\mathrm{Ca}$ & $\mathrm{Mg}$ & $\mathrm{K}$ & Total N & $\mathrm{P}$ & $\mathrm{S}$ & $\mathrm{B}$ & $\mathrm{Zn}$ & $\mathrm{Cu}$ \\
\cline { 3 - 12 } & & $\%$ & \multicolumn{6}{|c}{ (meq /100g soil) } & $\%$ & \multicolumn{6}{c}{ (ug/g soil) } \\
\hline Sandy loam & 5.9 & 1.12 & 2.8 & 0.91 & 0.28 & 0.071 & 28 & 18 & 0.11 & 1.13 & 0.07 \\
Critical level & - & - & 2.0 & 0.8 & 0.20 & - & 14 & 14 & 0.2 & 2.0 & 0.2 \\
\hline
\end{tabular}

Table 2. Nutrient status of organic manure used in the experiment

\begin{tabular}{lcccc}
\hline \multirow{2}{*}{ Organic Sources } & \multicolumn{4}{c}{ Nutrient content } \\
\cline { 2 - 5 } & $\mathrm{N}(\%)$ & $\mathrm{P}(\%)$ & $\mathrm{K}(\%)$ & $\mathrm{S}(\%)$ \\
\hline Cowdung & 0.90 & 0.7 & 0.75 & 0.35 \\
Poultry manure & 1.90 & 1.6 & 1.65 & 1.55 \\
Vermicompost & 1.25 & 1.28 & 1.45 & 1.02 \\
\hline
\end{tabular}

\section{Nutrient analysis of plant}

The plant sample (seed and stover) of fenugreek were collected from each plot and were dried for $48 \mathrm{hrs}$ in hot air oven at $65 \pm 5^{\circ} \mathrm{C}$. These dried samples were partitioned into seed and stover. Finally ground samples were passed through $0.5 \mathrm{~mm}$ mesh sieve and were used for chemical determination of nitrogen, phosphorus and potassium concentration as described by Nitrogen concentration (Modified microkjeldahl method), Phosphorus concentration

(Wet digestion molybdo phosphoric acid method), Potassium concentration (Flame emission spectrophotometer method) by Jackson, 1973

Uptake of NPK: The total respective nutrient uptake by fenugreek from each treatment was calculated as follows:

i. Nitrogen uptake $\left(\mathrm{kg} \mathrm{ha}^{-1}\right)$ 


$$
=\frac{\mathrm{N} \text { content in seed }(\%) * \text { seed yield }\left(\mathrm{kg} \mathrm{ha}^{-1}\right)+\mathrm{N} \text { content in stover }(\%) * \text { stover yield }\left(\mathrm{kg} \mathrm{ha}^{-1}\right)}{100}
$$

ii. Phosphorus uptake $\left(\mathrm{kg} \mathrm{ha}^{-1}\right)$

$$
=\frac{\mathrm{P} \text { content in seed }(\%) * \text { seed yield }\left(\mathrm{kg} \mathrm{ha}^{-1}\right)+\mathrm{P} \text { content in stover }(\%) * \text { stover yield }\left(\mathrm{kg} \mathrm{ha}^{-1}\right)}{100}
$$

iii. Potassium uptake $\left(\mathrm{kg} \mathrm{ha}^{-1}\right)$

$$
=\frac{\mathrm{K} \text { content in seed }(\%) * \text { seed yield }\left(\mathrm{kg} \mathrm{ha}^{-1}\right)+\mathrm{K} \text { content in stover }(\%) * \text { stover yield }\left(\mathrm{kg} \mathrm{ha}^{-1}\right)}{100}
$$

\section{Protein content in seed}

The protein content in seed was calculated by multiplying the nitrogen content of seed by 6.25 . Protein yield was obtained by using the following formula:

iv. Protein yield $\left(\mathrm{kg} \mathrm{ha}^{-1}\right)=\frac{\text { Protein content }(\%) * \text { seed yield }\left(\mathrm{kg} \mathrm{ha}^{-1}\right)}{100}$

\section{Statistical analysis}

The recorded data on different parameters were statistically analyzed by using MSTAT software and the difference between the treatment means were judged by Duncan's Multiple Range Test (DMRT) according to Gomez and Gomez, (1984).

\section{RESULTS AND DISCUSSION}

The pooled analysis was done because there was no significant differences in yield and nutrient content in both the years.

\section{Yield and yield attributes}

The yield attributes of fenugreek were profoundly influenced due to combined use of organic and inorganic sources and indicated significant difference with respect to pod length, pods plant ${ }^{-1}$ and test weight. Application of $4 \mathrm{t} \mathrm{ha}^{-1} \mathrm{PM}+\mathrm{CF}$ (IPNS) recorded highest pod length $(14.2 \mathrm{~cm})$, pods plant ${ }^{-1}(142.2)$ and test weight $(13.7 \mathrm{~g})$. It was closely followed by application of $5 \mathrm{tha}^{-1} \mathrm{CD}+\mathrm{CF}$ (IPNS) and $3 \mathrm{tha}-{ }^{-1} \mathrm{VC}+\mathrm{CF}$ (IPNS). Number of seeds per pod was not significant among the treatments. The result showed that the significant increase in seed yield was recorded due to use of integrated nutrient management. The maximum seed $\left(2.10 \mathrm{t} \mathrm{ha}^{-1}\right)$ yield was found with the application of poultry manure $\left(4 \mathrm{t} \mathrm{ha}^{-1}\right)$ along with chemical fertilizer $\left(\mathrm{T}_{7}\right)$ but statistically at par to $\mathrm{T}_{8}$ and $\mathrm{T}_{6}$ (Table 4). The application of nutrients through various source and their integrations significantly influenced the seed and stover yield over control. The lower amount of organic manure and only chemical fertilizer showed lower significantly lower seed yield than higher amount of organic manure. 
Table 3. Effect of Integrated nutrient management on yield and yield contributing characters of fenugreek (pooled of 2 years)

\begin{tabular}{|c|c|c|c|c|c|c|c|c|}
\hline Treatment & $\begin{array}{l}\text { Plant } \\
\text { height } \\
(\mathrm{cm})\end{array}$ & $\begin{array}{l}\text { No. of } \\
\text { branch } \\
\text { es } \\
\text { plant }^{-1}\end{array}$ & $\begin{array}{l}\text { No. of } \\
\text { pods } \\
\text { plant }^{-1}\end{array}$ & $\begin{array}{l}\text { Length } \\
\text { of pod } \\
(\mathrm{cm})\end{array}$ & $\begin{array}{l}\text { No. of } \\
\text { seeds } \\
\text { pod }^{-1}\end{array}$ & $\begin{array}{c}\text { Test } \\
\text { weight }(\mathrm{g})\end{array}$ & $\begin{array}{c}\text { Seed } \\
\text { yield } \\
\left(\mathrm{tha}^{-1}\right)\end{array}$ & $\begin{array}{c}\text { Stover } \\
\text { yield } \\
\left(\text { tha }^{-1}\right)\end{array}$ \\
\hline $\mathrm{T}_{1}=$ Absolute control & $56.2 d$ & $4.2 \mathrm{c}$ & $66.2 \mathrm{e}$ & $7.1 \mathrm{c}$ & 11.88 & $9.40 \mathrm{e}$ & $0.82 \mathrm{f}$ & $1.95 f$ \\
\hline $\mathrm{T}_{2}=\mathrm{CF}$ on the basis of STB & $94.6 a b$ & $10.2 \mathrm{ab}$ & $101.2 \mathrm{c}$ & $10.7 \mathrm{ab}$ & 12.18 & $12.30 \mathrm{abc}$ & $1.88 \mathrm{bc}$ & $4.32 \mathrm{bc}$ \\
\hline $\begin{array}{l}\mathrm{T}_{3}=\mathrm{CD} @ 3 \mathrm{tha}^{-1}+\mathrm{CF} \\
(\mathrm{IPNS})\end{array}$ & $83.1 \mathrm{bc}$ & $7.1 \mathrm{bc}$ & $95.6 \mathrm{~cd}$ & $8.05 \mathrm{bc}$ & 12.05 & $11.30 \mathrm{~cd}$ & 1.36de & $3.13 \mathrm{~d}$ \\
\hline $\begin{array}{l}\mathrm{T}_{4}=\mathrm{PM} @ 2 \mathrm{tha}^{-1}+\mathrm{CF} \\
(\mathrm{IPNS})\end{array}$ & $85.6 \mathrm{bc}$ & $8.2 \mathrm{bc}$ & $95.1 \mathrm{~cd}$ & $9.0 \mathrm{ab}$ & 12.38 & $11.45 \mathrm{c}$ & $1.42 \mathrm{~d}$ & $3.27 \mathrm{~d}$ \\
\hline $\begin{array}{l}\mathrm{T}_{5}=\mathrm{VC} @ 1 \mathrm{tha}^{-1}+\mathrm{CF} \\
(\text { IPNS) }\end{array}$ & $72.2 \mathrm{c}$ & $6.9 \mathrm{bc}$ & $86.5 \mathrm{~d}$ & $9.25 \mathrm{ab}$ & 12.25 & $11.35 \mathrm{~cd}$ & $1.37 \mathrm{de}$ & $3.18 \mathrm{~d}$ \\
\hline $\begin{array}{l}\mathrm{T}_{6}=\mathrm{CD} @ 5 \mathrm{tha}^{-1}+\mathrm{CF} \\
(\mathrm{IPNS})\end{array}$ & $92.2 \mathrm{abc}$ & $10.5 \mathrm{ab}$ & $138.8 \mathrm{a}$ & $14.0 \mathrm{a}$ & 12.88 & $12.70 \mathrm{ab}$ & $1.90 \mathrm{ab}$ & $4.39 \mathrm{bc}$ \\
\hline $\begin{array}{l}\mathrm{T}_{7}=\mathrm{PM} @ 4 \mathrm{tha}^{-1}+\mathrm{CF} \\
(\mathrm{IPNS})\end{array}$ & $101.6 \mathrm{a}$ & $15.6 \mathrm{a}$ & $142.2 \mathrm{a}$ & $14.2 \mathrm{a}$ & 13.55 & $13.02 \mathrm{a}$ & $2.10 \mathrm{a}$ & $4.89 \mathrm{a}$ \\
\hline $\begin{array}{l}\mathrm{T}_{8}=\mathrm{VC} @ 3 \mathrm{tha}^{-1}+\mathrm{CF} \\
\text { (IPNS) }\end{array}$ & $97.5 \mathrm{ab}$ & $13 \mathrm{ab}$ & $132.0 \mathrm{ab}$ & $13.5 \mathrm{a}$ & 12.93 & $12.80 \mathrm{ab}$ & $1.95 \mathrm{ab}$ & $4.56 \mathrm{~b}$ \\
\hline $\operatorname{LSD}(0.05)$ & 2.67 & 0.79 & 1.2 & 0.18 & 0.25 & 0.36 & 0.4 & 0.6 \\
\hline
\end{tabular}

Means having same letter(s) do not differ significantly at $5 \%$ level of probability

\section{Nutrient content and uptake}

Integrated application of nutrients significantly increased the $\mathrm{N}, \mathrm{P}$ and $\mathrm{K}$ content in seed and stover (Table 4 ) and their uptake as well as protein content in seed by application of nutrients through various sources of organic and inorganic fertilizer (Table 5). The nutrient uptake was significantly higher with the application of PM @ $4 \mathrm{tha}^{-1}+\mathrm{CF}$ (IPNS) to the tune of $75 \mathrm{~kg} \mathrm{~N} \mathrm{ha}^{-1}, 11.52 \mathrm{~kg} \mathrm{P} \mathrm{ha}^{-1}$ and $43.11 \mathrm{~kg}$ $\mathrm{K} \mathrm{ha}^{-1}$ over control (Table $5 \& 6$ ). Single application of chemical fertilizer and lower amount of organic manure also showed lower concentration of NPK. Organic manure (vermicompost and cow-dung) failed to show higher conc. of NPK than poultry manure. Decomposition of organic manures is accompanied by the release of appreciable quantities of $\mathrm{CO}_{2}$, which get dissolved in water to form carbonic acid. Carbonic acid is capable of decomposition of certain primary minerals and release of nutrients and favors higher biomass production and nutrient uptake (Dahama, 2003). 
Table 4. Effect of integrated nutrient management on nitrogen and phosphorus uptake of fenugreek (pooled of 2 years)

\begin{tabular}{|c|c|c|c|c|c|c|}
\hline \multirow[t]{2}{*}{ Treatment } & \multicolumn{2}{|c|}{$\mathrm{N}$ content $(\%)$} & \multirow{2}{*}{$\begin{array}{c}\text { Total N } \\
\text { uptake }(\mathrm{kg} \\
\left.\mathrm{ha}^{-1}\right)\end{array}$} & \multicolumn{2}{|c|}{$\mathrm{P}$ content $(\%)$} & \multirow{2}{*}{$\begin{array}{c}\text { Total P } \\
\text { uptake }(\mathrm{kg} \\
\left.\mathrm{ha}^{-1}\right)\end{array}$} \\
\hline & Seed & Stover & & Seed & Stover & \\
\hline $\mathrm{T}_{1}=$ Absolute control & $2.45 \mathrm{~b}$ & $0.75 \mathrm{c}$ & $37.72 \mathrm{e}$ & $0.291 \mathrm{~d}$ & $0.092 \mathrm{~b}$ & $4.18 \mathrm{f}$ \\
\hline $\mathrm{T}_{2}=\mathrm{CF}$ on the basis of STB & $3.40 \mathrm{a}$ & $0.82 \mathrm{a}$ & $99.34 \mathrm{bc}$ & $0.409 b$ & $0.102 \mathrm{ab}$ & $12.10 \mathrm{bc}$ \\
\hline $\mathrm{T}_{3}=\mathrm{CD} @ 3 \mathrm{tha}^{-1}+\mathrm{CF}(\mathrm{IPNS})$ & $3.26 \mathrm{ab}$ & $0.66 b$ & $64.99 \mathrm{~cd}$ & $0.360 \mathrm{bc}$ & $0.105 \mathrm{ab}$ & $8.18 \mathrm{de}$ \\
\hline $\mathrm{T}_{4}=\mathrm{PM} @ 2 \mathrm{tha}^{-1}+\mathrm{CF}$ (IPNS) & $3.27 \mathrm{ab}$ & $0.67 b$ & $68.34 \mathrm{~cd}$ & $0.375 b c$ & $0.107 \mathrm{ab}$ & $8.82 \mathrm{~d}$ \\
\hline $\mathrm{T}_{5}=\mathrm{VC} @ 1 \mathrm{tha}^{-1}+\mathrm{CF}$ (IPNS) & $3.26 \mathrm{ab}$ & $0.67 b$ & $65.97 \mathrm{~cd}$ & $0.369 \mathrm{bc}$ & $0.108 \mathrm{ab}$ & $8.49 \mathrm{de}$ \\
\hline $\mathrm{T}_{6}=\mathrm{CD} @ 5 \mathrm{tha}^{-1}+\mathrm{CF}(\mathrm{IPNS})$ & $3.34 \mathrm{a}$ & $0.81 \mathrm{a}$ & $99.02 \mathrm{bc}$ & $0.436 \mathrm{ab}$ & $0.110 \mathrm{ab}$ & $13.11 b c$ \\
\hline $\mathrm{T}_{7}=\mathrm{PM} @ 4 \mathrm{tha}^{-1}+\mathrm{CF}(\mathrm{IPNS})$ & $3.43 \mathrm{a}$ & $0.84 \mathrm{a}$ & $113.12 \mathrm{a}$ & $0.488 \mathrm{a}$ & $0.117 \mathrm{a}$ & $15.97 \mathrm{a}$ \\
\hline $\mathrm{T}_{8}=\mathrm{VC} @ 3 \mathrm{t} \mathrm{ha}^{-1}+\mathrm{CF}$ (IPNS) & $3.37 \mathrm{a}$ & $0.82 \mathrm{a}$ & $103.12 b$ & $0.475 \mathrm{a}$ & $0.106 \mathrm{ab}$ & $14.10 \mathrm{~b}$ \\
\hline $\operatorname{LSD}(0.05)$ & 0.37 & 0.8 & 3.45 & 0.004 & 0.004 & 1.45 \\
\hline
\end{tabular}

Means having same letter(s) do not differ significantly at 5\% level of probability.

It is an established fact that nutrient uptake by the crop depends mainly on the dry matter accumulation followed by the nutrient content at cellular level. The increased total dry matter production and nutrient content in plants seems to be the major causes responsible for the higher $\mathrm{N}$ and $\mathrm{P}$ uptake under the influence of integrated nutrient management. The increased protein content in seed is directly correlated with $\mathrm{N}$ content in seed. The increased $\mathrm{N}$ content in seed resulted into higher protein content due to integrated nutrient management. The present trend of increased $\mathrm{N}, \mathrm{P}$ and $\mathrm{K}$ contents in seed and stover, their uptake and higher protein content in seed under the influence of integrated nutrient management as reported by Khiriya et al. (2003). 
Table 5. Effect of integrated nutrient management on potassium uptake and quality parameters of fenugreek (pooled of 2 years)

\begin{tabular}{|c|c|c|c|c|c|}
\hline \multirow[t]{2}{*}{ Treatment } & \multicolumn{2}{|c|}{ K content $(\%)$} & \multirow{2}{*}{$\begin{array}{l}\text { Total K uptake } \\
\qquad\left(\mathrm{kg} \mathrm{ha}^{-1}\right)\end{array}$} & \multirow{2}{*}{$\begin{array}{l}\text { Seed protein } \\
\text { content }(\%)\end{array}$} & \multirow{2}{*}{$\begin{array}{c}\text { Protein } \\
\text { yield } \\
\left(\mathrm{kg} \mathrm{ha}^{-1}\right)\end{array}$} \\
\hline & Seed & Stover & & & \\
\hline $\mathrm{T}_{1}=$ Absolute control & $0.672 d$ & $0.885 \mathrm{ab}$ & $22.77 \mathrm{~d}$ & $15.31 b$ & $125.54 \mathrm{c}$ \\
\hline $\mathrm{T}_{2}=\mathrm{CF}$ on the basis of STB & $0.906 \mathrm{ab}$ & $0.918 \mathrm{ab}$ & $56.69 \mathrm{bc}$ & $21.25 \mathrm{a}$ & $399.50 \mathrm{a}$ \\
\hline $\mathrm{T}_{3}=\mathrm{CD} @ 3 \mathrm{tha}^{-1}+\mathrm{CF}($ IPNS $)$ & $0.867 \mathrm{bc}$ & $0.923 \mathrm{ab}$ & $40.68 \mathrm{~cd}$ & $20.38 \mathrm{ab}$ & $277.17 b$ \\
\hline $\mathrm{T}_{4}=\mathrm{PM} @ 2 \mathrm{tha}^{-1}+\mathrm{CF}$ (IPNS) & $0.868 \mathrm{bc}$ & $0.925 \mathrm{ab}$ & $42.57 \mathrm{~cd}$ & $20.44 \mathrm{ab}$ & $290.25 b$ \\
\hline $\mathrm{T}_{5}=\mathrm{VC} @ 1 \mathrm{tha}^{-1}+\mathrm{CF}(\mathrm{IPNS})$ & $0.866 \mathrm{bc}$ & $0.926 \mathrm{ab}$ & $41.31 \mathrm{~cd}$ & $20.38 \mathrm{ab}$ & $279.21 b$ \\
\hline $\mathrm{T}_{7}=\mathrm{CD} @ 5 \mathrm{tha}^{-1}+\mathrm{CF}($ IPNS $)$ & $0.908 \mathrm{ab}$ & $0.915 \mathrm{ab}$ & $57.42 \mathrm{bc}$ & $20.88 \mathrm{a}$ & $396.72 \mathrm{a}$ \\
\hline $\mathrm{T}_{7}=\mathrm{PM} @ 4 \mathrm{t} \mathrm{ha}^{-1}+\mathrm{CF}$ (IPNS) & $0.918 \mathrm{a}$ & $0.953 \mathrm{a}$ & $65.88 \mathrm{a}$ & $21.44 \mathrm{a}$ & $450.24 \mathrm{a}$ \\
\hline $\mathrm{T}_{8}=\mathrm{VC} @ 3 \mathrm{tha}^{-1}+\mathrm{CF}$ (IPNS) & $0.915 \mathrm{a}$ & $0.951 \mathrm{a}$ & $61.21 \mathrm{~b}$ & $21.06 \mathrm{a}$ & $410.67 \mathrm{a}$ \\
\hline $\operatorname{LSD}(0.05)$ & 0.003 & 0.006 & 4.56 & 0.35 & 7.67 \\
\hline
\end{tabular}

Means having same letter(s) do not differ significantly at $5 \%$ level of probability.

Application of poultry manure $4 \mathrm{t} \mathrm{ha}^{-1}$ along with chemical fertilizer resulted higher protein content but statistically identical to $\mathrm{T}_{8} \& \mathrm{~T}_{6}$ treatment than all other treatments (Table 5). Nitrogen alone or in combination with organic fertilizer increased protein content due to nitrogen. Nitrogen is a basic constituent of protein. Organic fertilizer increased nitrogen availability, which resulted in higher protein content in seed. The results are in conformity with Nagre (1991).

\section{Organic carbon and Soil fertility}

The organic carbon and soil fertility (available N, P and K) in fenugreek was markedly improved due to integrated application of nutrient management of organic and inorganic sources over control (Table 6). Integrated application of poultry manure (PM), vermicompost (VC) and cowdung (CD) along with chemical fertilizer resulted in improvement in organic carbon content of the soil over the initial content. Similarly, available N, P and K status of soil was noticed in the same trend. Slightly higher total $\mathrm{N}(0.095 \%)$, available $\mathrm{P}(18.04 \mathrm{ppm})$ and exchangeable $\mathrm{K}(18.28 \mathrm{meq}$ \%) was recorded in $\mathrm{T}_{7}=\mathrm{PM} @ 4 \mathrm{t} \mathrm{ha}^{-1}+\mathrm{CF}$ (IPNS) which might be due to higher $\mathrm{N}$, $\mathrm{P}$ and $\mathrm{K}$ content in the poultry manure in comparison to other organic source. The higher organic carbon content by PM application could be attributed to the soil improvement. Organic manures on decomposition solubilize insoluble $\mathrm{P}$ fractions through release of various organic acids and increase the available P status of soil. It also forms chelates with essential plant nutrients and their fixation which favor availability of nutrient to crop (Parihar and Rana, 2010). The higher P content of PM in comparison to other organic source might have resulted in the higher available $\mathrm{P}$ content of the soil. The improvement in soil fertility after crop harvest due to integrated nutrient management was also recorded by Parihar et al. (2009). 
Table 6. Influence of integrated nutrient management on post harvest soil nutrient status

\begin{tabular}{c|c|c|c|c}
\hline \multirow{2}{*}{ Treatment } & \multicolumn{4}{c}{ Soil nutrient status } \\
\cline { 2 - 5 } & Organic C (\%) & Total N \% & Available P (ppm) & $\begin{array}{c}\text { Exchangeable K } \\
\text { (me\%) }\end{array}$ \\
\hline $\mathrm{T}_{1}=$ Absolute control & $0.17 \mathrm{c}$ & $0.065 \mathrm{a}$ & $16.95 \mathrm{c}$ & $11.02 \mathrm{c}$ \\
$\mathrm{T}_{2}=\mathrm{CF}$ on the basis of STB & $0.18 \mathrm{bc}$ & $0.093 \mathrm{a}$ & $17.86 \mathrm{a}$ & $17.98 \mathrm{ab}$ \\
$\mathrm{T}_{3}=\mathrm{CD} @ 3 \mathrm{t} \mathrm{ha}^{-1}+\mathrm{CF}$ (IPNS) & $0.20 \mathrm{ab}$ & $0.088 \mathrm{a}$ & $17.20 \mathrm{bc}$ & $16.42 \mathrm{~b}$ \\
$\mathrm{~T}_{4}=\mathrm{PM} @ 2 \mathrm{t} \mathrm{ha}^{-1}+\mathrm{CF}$ (IPNS) & $0.21 \mathrm{ab}$ & $0.089 \mathrm{a}$ & $17.42 \mathrm{bc}$ & $16.45 \mathrm{~b}$ \\
$\mathrm{~T}_{5}=\mathrm{VC} @ 1 \mathrm{t} \mathrm{ha}^{-1}+\mathrm{CF}$ (IPNS) & $0.20 \mathrm{ab}$ & $0.088 \mathrm{a}$ & $17.37 \mathrm{ab}$ & $16.44 \mathrm{~b}$ \\
$\mathrm{~T}_{6}=\mathrm{CD} @ 5 \mathrm{t} \mathrm{ha}^{-1}+\mathrm{CF}$ (IPNS) & $0.24 \mathrm{a}$ & $0.092 \mathrm{a}$ & $17.95 \mathrm{a}$ & $18.06 \mathrm{a}$ \\
$\mathrm{T}_{7}=\mathrm{PM} @ 4 \mathrm{t} \mathrm{ha}^{-1}+\mathrm{CF}$ (IPNS) & $0.25 \mathrm{a}$ & $0.095 \mathrm{a}$ & $18.04 \mathrm{a}$ & $18.28 \mathrm{a}$ \\
$\mathrm{T}_{8}=\mathrm{VC} @ 3 \mathrm{t} \mathrm{ha}^{-1}+\mathrm{CF}$ (IPNS) & $0.25 \mathrm{a}$ & $0.090 \mathrm{a}$ & $17.98 \mathrm{a}$ & $18.12 \mathrm{a}$ \\
\hline $\mathrm{LSD}^{2}$ (0.05) & 0.003 & 0.003 & 1.77 & 2.37 \\
\hline
\end{tabular}

Means having same letter(s) do not differ significantly at 5\% level of probability.

\section{CONCLUSION}

On the basis of experimental results, it is clearly observed that integrated application of nutrients significantly increased the seed yield, nutrient and protein content in seed and stover by application of nutrients through various sources. Application of poultry manure @ $4 \mathrm{t} \mathrm{ha}^{-1}+\mathrm{CF}$ through IPNS) appeared as the best combination for maximizing the yield of fenugreek as well as soil improvement of Tista Karatoa flood Plain under AEZ-3. Organic manure (VC \& CD) with chemical fertilizer (IPNS) may be alternative source of improvement of soil health as well as yield of fenugreek.

\section{REFERENCES}

Boateng, S., Zickermann, A. J. and Kornaharens, M. 2006. Effect of poultry manure on growth and yield of maize. West African Journal of Applied Ecology, 9:1-11

Dahama, A. K. 2003. Organic Farming for Sustainable Agriculture. $2^{\text {nd }}$ Edn., Agrobios, Jodhpur, pp 91-124

Dwivedi, A. K., Singh, S. and Ranjan, R. 2006.Suitable varieties of fenugreek for Jharkhand spices and medicinal and Aromatic plants in eastern region pp. 95-101

Gomez, K. A. and Gomez, A. A. 1984. Statistical Procedures for Agricultural Research. $2^{\text {nd }}$ edn. Second Edition. An International Rice Research Institute Book. A Wiley-Inter science Publication, John Wiley and Sons, New York 
Jackson M. C. 1973. Soil chemist Analysis.Prentice Hall Pvt. Ltd. India

Jat R. S. and Ahlawat J. P. S. 2006. Effect of vermicompost biofertilizers and P on growth, yield and nutrient uptake by gram and their residual effect on fodder maize. Indian Journal of Agricultural Science, 74(7): 359-361

Jeyabal A., Palaniappan S. P. and Chelliah S. 2000. Effect of integrated nutrient management techniques on yield attributes and yield of sunflower (Helianthus annus). Indian Journal of Agronomy, 45(2): 384- 388

Khiriya K. D. and Singh B. P. 2003. Effect of phosphorus and farmyard manure on yield, yield attributes and nitrogen, phosphorus and potassium uptake of fenugreek (Trigonella foenumgraecum). Indian Journal Agronomy, 48(1): 62-65

Kumar N., Khader J. M. A., Rangaswami P. and Irulappan I. 1997. Introduction to spices, plantation crops, medicinal and aromatic plants. pp 306.

Nambiar, K. K. M. and Abrol, I. P. 1989. Long term fertilizer experiments in India-An overview. Fertilizer News, 34(4): 11-20

Nagre K. T., Deshmukh S. B., Bhalerao P. D. and Thorve P. V. 1991. Effect of sowing dates and fertilizers on growth, yield and quality of soybean varieties. P.K.V. Research Journal, 15(1): 81-84

Parihar, C. M., Rana, K. S. and Parihar, M. D. 2009. Crop productivity quality and nutrient uptake of pearlmillet (Pennisetum glaucum)-mustard (Brassica juncea) cropping system as influenced by land configuration and direct and residual effect of nutrient management. Indian Journal of Agricultural Sciences, 79(11): 927-30

Parihar, C. M. and Rana, K. S. 2010. Nutrient management in pearlmillet (Pennisetum glaucum)-mustard (Brassica juncea) cropping system as affected by land configuration under limited irrigation. Indian Journal of Agronomy, 55(3): 191-96

Subbian, P. and Palaniappan, S. P. 1992. Effect of Integrated management practices on the yield and economics of crop under high intensity multiple cropping system. Indian Journal Agronomy, 37(1): 1-5

Warren, J. G., Phillips, S. B., Mullins, G. L., Keahey, D. and Penn, C. J. 2006. Environmental and production consequences of using alumamended poultry litter as a nutrient source for corn. Journal of Environmental Quality, 35: 172-182 